Research Article

\title{
Factors affecting the vaccination coverage of children under five years in central India
}

\author{
Maheshwari $\mathbf{M}^{1}$, Gedam DS $^{3}$, Patel $\mathbf{U}^{3}, \operatorname{Masood} \mathrm{A}^{4}$ \\ ${ }^{1}$ Dr Mahesh Maheshwari, Associate Professor, Peoples Medical College and Research Centre, Bhopal, MP, India, ${ }^{2}$ Dr D \\ Sharad Gedam, Associate Professor, Department of Pediatrics, L N Medical College, Bhopal, MP, India, ${ }^{3}$ Dr. Umesh Patel, \\ Associate Professor, LN Medical College, Bhopal (MP), ${ }^{4}$ Dr. Altaf Masood, Consultant Pediatrics, Bhopal, MP, India.
}

Address for Correspondence: Dr. Umesh Patel, drumeshpatel@gmail.com

\begin{abstract}
Background: Despite a dramatic reduction in disease burden of vaccine-preventable diseases through childhood immunization, vaccine coverage is not satisfactory even in urban slums. We need considerable efforts to ensure adequate vaccine coverage to control morbidity and mortality. Objective: To assess the immunization coverage in an urban slum area and determine various socio-demographic factors affecting the vaccination coverage. Material and Methods: It is a cross sectional random sample study. Parents of children upto the age of 5 years were interviewed at their homes and vaccination centers. Total 1514 cases were included in this study. Results: Approximately $58.9 \%$ of the children were fully vaccinated, $23 \%$ children were partially vaccinated and $18.2 \%$ children were unvaccinated. The full vaccination rate increased with lower birth order, education level of the parents, socioeconomic status of family and hospital delivery. Conclusion: Children from higher economic or educational groups had better vaccination coverage. Not known of exact date of vaccination is most important factor for poor vaccination coverage. Lack of time, distance and nobody at home were the other factors having negative impact.
\end{abstract}

Keywords: Vaccination, Socioeconomic Status, Coverage

\section{Introduction}

Survival is the biggest challenge for children younger than five years old, especially for those under one year This become more challenging again, if children belong to underprivileged sectors especially slums. Immunization is definitely one of the most effective and cost effective ways of protecting the health of infants and children worldwide against few most lethal and debilitating diseases. Immunization is one of the greatest public health achievements of 20th century, but for effective immunization effect, population coverage levels of particular vaccine should be between 90 to $95 \%$ [2]. Despite tremendous advances in economic, technological and medical field in recent years, the burden of vaccinepreventable diseases remains unacceptably high in underdeveloped and developing countries [3].

Roughly 3 million children die each year of vaccine preventable diseases (VPDs) with a disproportionate number of these children residing in developing countries [4]. World Health Organization has started the "Expande d

Manuscript received: $5^{\text {th }}$ Jan 2014

Reviewed: $11^{\text {th }}$ Jan 2014

Author Corrected; $17^{\text {th }}$ Jan 2014

Accepted for Publication: $21^{\text {st }}$ January 2014
Programme of Immunization" (EPI) globally in 1974. India was one of the first few countries to adopt this programme. In India EPI was started in 1978. To increase the coverage and focus on upto one year of age, the UIP was introduced by the Government of India in 1985-86 to cover at least 85 per cent of the infants against the six vaccine-preventable diseases by 1990 [4]. It was hoped that by end of 20th century, the coverage of children for vaccination against these six vaccine preventable diseases would reach 100 per cent. Since its inception, life of millions of children have been saved. Although India has had remarkable success in immunization coverage, a gap still exists between urban and rural areas, literate and illiterate, upper and lower socioeconomic status, home delivery and hospital delivery etc. Even if national immunization coverage levels are sufficiently high to block disease transmission, pockets of susceptibility may act as potential reservoirs of infection

[6]. It is therefore essential to know those pockets and take necessary action to fulfill the vaccine coverage gap. Thus present study was under taken to assess the immunization coverage and various socio-demographic factors affecting the urban slum population of Bhopal (MP), India. 


\section{Aim and Objective}

1. To study the vaccination status of children under five years in urban slums of Bhopal

2. To study the influence of age, sex, religion, socioeconomic status, parental literacy, parental occupation, family size, birth order of child, place of delivery and availability of vaccination cord on vaccination status.

3. To study of attitudes, beliefs, myths and awareness regarding child vaccination

4. To study the PPI (Pulse Polio Immunization) during the study period and effect of PPI on routine vaccination.

\section{Material and Methods}

This is cross sectional random sample survey study. It is conducted between May 1999 to June 2000 in one urban slums of Bhopal city. Parents of children upto 5 years of age were included in the study. Parents were interviewed after proper explanation about the nature of study. Information was tactfully obtained and recorded on the special proforma. Interview were conducted at their homes booth of PPI. Help of local aganwadi workers were taken for the confirmation of vaccination while visiting those areas covered by ICDS.

Details were closely confirmed by observation and cross questioning. Parents were interrogated thoroughly about their attitudes towards immunization. Every effort was made to elicit an answer from the parents. Those who have not given vaccination to their children were asked for reason for failure to give vaccine, they were advocated for immunization and directed to nearest aganwadi or hospital.

\section{Results}

Table No: 01: Distribution different parameters of children $(n=1514)$

\begin{tabular}{|c|c|c|c|c|c|c|c|}
\hline \multicolumn{2}{|c|}{ Age distribution } & \multicolumn{2}{|c|}{$\begin{array}{l}\text { Birth order } \\
\text { distribution }\end{array}$} & \multicolumn{4}{|l|}{ Vaccination status } \\
\hline $\begin{array}{c}\text { Age } \\
\text { (Months) }\end{array}$ & $\begin{array}{l}\text { Total } \\
(\%)\end{array}$ & $\begin{array}{l}\text { Birth } \\
\text { Order }\end{array}$ & $\begin{array}{l}\text { Total } \\
(\%)\end{array}$ & Status & Male & Female & Total \\
\hline $00-06$ & $153(10.1)$ & $1 \mathrm{st}$ & $506(33.4)$ & No of children & $838(55.3)$ & $676(44.6)$ & $1514(100)$ \\
\hline $06-12$ & $158(10.4)$ & 2 nd & $417(31.1)$ & Vaccinated & $494(58.9)$ & $400(59.2)$ & $894(59.1)$ \\
\hline $13-24$ & $297(19.6)$ & $3 \mathrm{rd}$ & 281(18.6) & Partially vaccinated & $263(31.3)$ & $179(26.5)$ & $442(29.2)$ \\
\hline $25-36$ & $295(19.5)$ & $4^{\text {th }}$ & $141(09.3)$ & Unvaccinated & $81(09.6)$ & $97(14.4)$ & $178(11.8)$ \\
\hline $37-48$ & $281(18.6)$ & $\geq 5^{\text {th }}$ & $115(07.6)$ & & & & \\
\hline $49-60$ & $330(21.8)$ & - & - & & & & \\
\hline Total & 1514 & Total & 1514 & & & & \\
\hline
\end{tabular}

Table No-1 depicts that majority of children belong to age group 13-60 months in both groups. First and second birth order cover $64.5 \%$ children. $59.1 \%$ children were fully vaccinated, where $11.8 \%$ children were unvaccinated.

Table No-02 : Vaccination Coverage \& Drop Out Percentage (n=1514)

\begin{tabular}{|c|c|c|c|c|c|c|c|}
\hline \multirow[t]{2}{*}{ Vaccines } & \multicolumn{4}{|c|}{ No of children vaccinated } & \multirow{2}{*}{$\begin{array}{c}\text { No of } \\
\text { children } \\
\text { missing }\end{array}$} & \multicolumn{2}{|c|}{ Drop Out \% } \\
\hline & Male & Female & Total & $\%$ & & $\begin{array}{c}\begin{array}{c}\text { From } \\
n=1514\end{array}\end{array}$ & $\begin{array}{c}\text { From } \\
\text { previous dose }\end{array}$ \\
\hline BCG+ Hepatitis B + OPV -0 & 757 & 579 & 1336 & 88.24 & 178 & 11.76 & 11.76 \\
\hline $\mathrm{DPT}+$ Hepatitis B $+\mathrm{OPV}\left(1^{\text {st }}\right)$ & 650 & 549 & 1199 & 79.19 & 315 & 20.80 & 10.41 \\
\hline $\mathrm{DPT}+$ Hepatitis B + OPV $\left(2^{\text {nd }}\right)$ & 622 & 512 & 1134 & 74.90 & 380 & 25.09 & 05.42 \\
\hline $\mathrm{DPT}+$ Hepatitis B + OPV $\left(3^{\text {rd }}\right)$ & 586 & 462 & 1048 & 69.22 & 466 & 30.77 & 07.58 \\
\hline Measles & 494 & 400 & 894 & 59.05 & 620 & 40.95 & 14.69 \\
\hline DPT + OPV (Booster-1) & 307 & 248 & 555 & 36.66 & 959 & 63.34 & 37.91 \\
\hline DPT + OPV (Booster-2) & 138 & 107 & 245 & 16.18 & 1269 & 83.81 & 55.85 \\
\hline
\end{tabular}


Table No: 02 shows that $88.24 \%$ children were vaccinated for BCG, Hepatitis B and OPV, where only $59.05 \%$ children were vaccinated for measles. By age of second booster (DPT \& OPV) $83.81 \%$ children were missing.

Table No-03 : Reasons for non-vaccination (Among partially vaccinated \& unvaccinated children)

\begin{tabular}{|c|c|c|c|c|c|c|}
\hline S. No & $\begin{array}{l}\text { Reasons for non-vaccination } \\
(\mathrm{n}=623)\end{array}$ & Total & $\%$ & $\begin{array}{l}\text { Reason for vaccination } \\
\qquad(\mathrm{n}=1563)^{*}\end{array}$ & Total & $\%$ \\
\hline 01 & $\begin{array}{l}\text { Lack of knowledge - } \\
\text { A. About vaccination } \\
\text { B. About place } \\
\text { C. About time }\end{array}$ & $\begin{array}{c}(348) \\
278 \\
38 \\
32\end{array}$ & $\begin{array}{c}(55.8) \\
44.6 \\
06.1 \\
05.1\end{array}$ & Prevent illness & 981 & 62.8 \\
\hline 02 & Time not available & 145 & 23.3 & Good for child & 174 & 11.1 \\
\hline 03 & Postpone for further date & 32 & 05.1 & Prevent disabilities & 167 & 10.7 \\
\hline 04 & Fear \& doubt & 31 & 05.0 & Prevent death & 39 & 02.5 \\
\hline 05 & Child illness & 23 & 03.7 & Other reasons & 17 & 01.1 \\
\hline 06 & Place of vaccination far away & 13 & 02.1 & Not known & 185 & 11.8 \\
\hline 07 & Other reasons $* *$ & 31 & 04.9 & & & \\
\hline
\end{tabular}

*Some of respondent given more than one reason

**Parental illness (10), wrong idea about when child should vaccinated (5), no faith in vaccination (9), rumors/religious factors (3), vaccinator not present (3), vaccines not available (1).

Table No: 03 depicts, lack of knowledge of vaccines, place and time was the biggest factors (in 55.8\% cases) for partially and non-vaccination. Time problem was the second most cause with $23.3 \%$ cases. Fear and childhood illness were also contribute significantly with $5.1 \%$ and $5 \%$.

Table No-04 : Relationship between parental education and vaccination coverage $(n=1514)$

\begin{tabular}{|c|c|c|c|c|c|c|c|}
\hline $\begin{array}{c}\text { Paternal } \\
\text { literacy }\end{array}$ & $\begin{array}{c}\text { Vaccinated } \\
(\%)\end{array}$ & $\begin{array}{c}\text { Partially } \\
\text { vaccinated }\end{array}$ & $\begin{array}{c}\text { Unvaccinated } \\
(\%)\end{array}$ & $\begin{array}{c}\text { Materna } \\
\text { l literacy }\end{array}$ & $\begin{array}{c}\text { Vaccinated } \\
(\%)\end{array}$ & $\begin{array}{c}\text { Partially } \\
\text { vaccinated }\end{array}$ & $\begin{array}{c}\text { Unvaccinat } \\
\text { ed } \\
(\%)\end{array}$ \\
\hline Illiterate & $271(30.3)$ & $191(43.2)$ & $76(42.7)$ & Illiterate & $377(42.2)$ & $165(37.3)$ & $98(55.1)$ \\
\hline Primary & $187(20.9)$ & $156(35.3)$ & $78(43.8)$ & Primary & $207(23.2)$ & $147(33.2)$ & $58(32.6)$ \\
\hline Middle & $198(22.1)$ & $48(10.8)$ & $10(05.6)$ & Middle & $143(15.9)$ & $77(17.4)$ & $19(10.7)$ \\
\hline $\begin{array}{c}\text { High. } \\
\text { Sec. }\end{array}$ & $155(17.3)$ & $41(09.3)$ & $11(06.2)$ & $\begin{array}{c}\text { High. } \\
\text { Sec. }\end{array}$ & $134(14.9)$ & $37(08.4)$ & $03(01.7)$ \\
\hline Graduate & $83(08.4)$ & $06(01.3)$ & $03(01.7)$ & Graduate & $33(03.7)$ & $16(03.6)$ & $00(00.0)$ \\
\hline Illiterate & $271(30.3)$ & $191(43.2)$ & $76(42.7)$ & Illiterate & $377(42.2)$ & $165(37.3)$ & $98(55.1)$ \\
\hline Literate & $623(69.7)$ & $251(56.8)$ & $102(57.3)$ & Literate & $544(60.8)$ & $277(62.7)$ & $80(44.9)$ \\
\hline Total & $\mathbf{8 9 4}$ & $\mathbf{4 4 2}$ & $\mathbf{1 7 8}$ & Total & $\mathbf{8 9 4}$ & $\mathbf{4 4 2}$ & $\mathbf{1 7 8}$ \\
\hline
\end{tabular}

Table No: 04 shows that in vaccinated children, $69.7 \%$ fathers and $60.8 \%$ mothers were literate, where as in unvaccinated group $42.7 \%$ father and $55.1 \%$ mothers were illiterate. Only $1.7 \%$ children of graduate fathers were unvaccinated, whereas non of children of graduate mother was unvaccinated.

Table No-05 : Relationship between parental occupation and vaccination coverage

\begin{tabular}{|c|c|c|c|c|c|c|c|}
\hline $\begin{array}{c}\text { Paternal } \\
\text { occupatio } \\
\mathbf{n}\end{array}$ & $\begin{array}{c}\text { Vaccinate } \\
\mathbf{d} \\
\mathbf{( \% )}\end{array}$ & $\begin{array}{c}\text { Partially } \\
\text { vaccinate } \\
\mathbf{d}\end{array}$ & $\begin{array}{c}\text { Unvaccinate } \\
\mathbf{d} \\
\mathbf{( \% )}\end{array}$ & $\begin{array}{c}\text { Maternal } \\
\text { occupatio } \\
\mathbf{n}\end{array}$ & $\begin{array}{c}\text { Vaccinate } \\
\mathbf{d} \\
\mathbf{( \% )}\end{array}$ & $\begin{array}{c}\text { Partially } \\
\text { vaccinate } \\
\mathbf{d}\end{array}$ & $\begin{array}{c}\text { Unvaccinated } \\
(\%)\end{array}$ \\
\hline $\begin{array}{c}\text { Govt } \\
\text { Service }\end{array}$ & $145(16.2)$ & $27(06.1)$ & $21(11.8)$ & $\begin{array}{c}\text { Govt } \\
\text { Service }\end{array}$ & $16(01.9)$ & $05(01.1)$ & $00(00.0)$ \\
\hline Business & $138(15.4)$ & $25(05.6)$ & $03(01.7)$ & Laborer & $174(19.5)$ & $70(15.8)$ & $107(60.1)$ \\
\hline Laborer & $421(47.1)$ & $342(77.4)$ & $105(58.9)$ & Others & $15(01.7)$ & $01(00.2)$ & $01(00.6)$ \\
\hline Others & $190(21.2)$ & $48(10.8)$ & $49(27.5)$ & $\begin{array}{c}\text { House } \\
\text { wife }\end{array}$ & $689(77.1)$ & $366(82.8)$ & $70(39.3)$ \\
\hline Total & $\mathbf{8 9 4}$ & $\mathbf{4 4 2}$ & $\mathbf{1 7 8}$ & Total & $\mathbf{8 9 4}$ & $\mathbf{4 4 2}$ & $\mathbf{1 7 8}$ \\
\hline
\end{tabular}


Table No: 05 depicts that in fully vaccinated group $47.1 \%$ children belong to laborer class family. In unvaccinated category $58.9 \%$ fathers and $60.1 \%$ mothers were laborer. $11.8 \%$ unvaccinated children belong to government services family. $77.1 \%$ vaccinated children's mothers were house wife.

Table No-06 : Relationship between birth order \& family size and vaccination coverage

\begin{tabular}{|c|c|c|c|c|c|c|c|}
\hline $\begin{array}{c}\text { Birth } \\
\text { order }\end{array}$ & $\begin{array}{c}\text { Vaccinated } \\
(\mathbf{\%})\end{array}$ & $\begin{array}{c}\text { Partially } \\
\text { vaccinated }\end{array}$ & $\begin{array}{c}\text { Unvaccinated } \\
(\mathbf{\%})\end{array}$ & $\begin{array}{c}\text { Family } \\
\text { size }\end{array}$ & $\begin{array}{c}\text { Vaccinated } \\
(\mathbf{\%})\end{array}$ & $\begin{array}{c}\text { Partially } \\
\text { vaccinated }\end{array}$ & $\begin{array}{c}\text { Unvaccinated } \\
(\%)\end{array}$ \\
\hline 1 & $403(45.1)$ & $103(23.3)$ & $53(29.7)$ & 3 to 5 & $504(56.4)$ & $210(47.5)$ & $49(27.5)$ \\
\hline 2 & $252(25.5)$ & $133(30.1)$ & $35(19.6)$ & 6 to 8 & $303(33.9)$ & $207(46.8)$ & $87(48.9)$ \\
\hline 3 & $143(15.9)$ & $81(18.3)$ & $31(17.4)$ & 9 to 11 & $77(08.6)$ & $23(05.2)$ & $33(18.5)$ \\
\hline 4 & $47(05.3)$ & $56(12.7)$ & $21(11.8)$ & 12 to 14 & $08(00.9)$ & $02(00.5)$ & $05(02.8)$ \\
\hline$>4$ & $49(05.5)$ & $69(15.6)$ & $38(21.3)$ & $>14$ & $02(00.2)$ & $00(00.0)$ & $04(02.2)$ \\
\hline Total & $\mathbf{8 9 4}$ & $\mathbf{4 4 2}$ & $\mathbf{1 7 8}$ & Total & $\mathbf{8 9 4}$ & $\mathbf{4 4 2}$ & $\mathbf{1 7 8}$ \\
\hline
\end{tabular}

Table No: 06 shows that $45.1 \%$ and $25.5 \%$ vaccinated children belong to birth order first and second. Similar $29.7 \%, 19.6 \%$ and $21.3 \%$ unvaccinated children belong to birth order $1^{\text {st }}, 2^{\text {nd }}$ and $5^{\text {th }}$ or more. Family size is also have great impact of vaccination coverage. $56.4 \%$ vaccinated children have 3-5 family members, whereas $33.9 \%$ have $6-8$ family members. In partially vaccinated category $47.5 \%$ children have $3-5$ family members. In un-vaccinated category $48.9 \%$ children belong to 6-8 member family size.

Table No-07 : Relationship between place of delivery \& Vaccination card and vaccination status

\begin{tabular}{|c|c|c|c|c|c|c|c|}
\hline $\begin{array}{c}\text { Place of } \\
\text { delivery }\end{array}$ & $\begin{array}{c}\text { Vaccinated } \\
(\mathbf{\%})\end{array}$ & $\begin{array}{c}\text { Partially } \\
\text { vaccinated }\end{array}$ & $\begin{array}{c}\text { Unvaccinated } \\
(\mathbf{\%})\end{array}$ & $\begin{array}{c}\text { Vaccination } \\
\text { card }\end{array}$ & $\begin{array}{c}\text { Vaccinated } \\
(\%)\end{array}$ & $\begin{array}{c}\text { Partially } \\
\text { vaccinated }\end{array}$ & $\begin{array}{c}\text { Unvaccinated } \\
(\%)\end{array}$ \\
\hline $\begin{array}{c}\text { Govt } \\
\text { Hospital }\end{array}$ & $484(54.1)$ & $213(48.2)$ & $75(42.1)$ & Yes & $578(64.7)$ & $248(56.1)$ & $85(47.7)$ \\
\hline $\begin{array}{c}\text { Private } \\
\text { Hospital }\end{array}$ & $153(17.1)$ & $26(05.9)$ & $10(05.6)$ & No & $316(35.3)$ & $194(43.9)$ & $93(52.3)$ \\
\hline Home & $257(28.8)$ & $203(25.9)$ & $93(52.2)$ & & & & \\
\hline Total & $\mathbf{8 9 4}$ & $\mathbf{4 4 2}$ & $\mathbf{1 7 8}$ & Total & $\mathbf{8 9 4}$ & $\mathbf{4 4 2}$ & $\mathbf{1 7 8}$ \\
\hline
\end{tabular}

Table No: 07 Shows that $54.1 \%$ vaccinated children delivered in government hospital where $28.8 \%$ delivered in home. Whereas 52.2\% unvaccinated children delivered at homes. $42.1 \%$ unvaccinated children also born in government hospital. Only $5.6 \%$ children, who were born in private hospital unvaccinated. $64.7 \%$ vaccinated children have vaccination card where $52.3 \%$ unvaccinated children don't have vaccination card.

Table No-08 : Relationship between socioeconomic status and vaccination coverage

\begin{tabular}{|c|c|c|c|}
\hline Socioeconomic Class & Vaccinated & Partially Vaccinated & Unvaccinated \\
\hline I & $21(02.3)$ & $05(01.1)$ & $02(01.1)$ \\
\hline II & $260(29.1)$ & $133(30.1)$ & $33(18.5)$ \\
\hline III & $262(29.3)$ & $88(19.9)$ & $35(19.7)$ \\
\hline IV & $351(39.3)$ & $216(48.8)$ & $108(60.7)$ \\
\hline Total & $\mathbf{8 9 4}$ & $\mathbf{4 4 2}$ & $\mathbf{1 7 8}$ \\
\hline
\end{tabular}

$\mathrm{X}^{2}$ value $=5.75 \mathrm{P}<0.05$ - Just significant

Table No:08 depicts that $39.3 \%$ vaccinated children belong to class IV socioeconomic status where as $29.3 \%$ and $29.1 \%$ belong to class III and class II socioeconomic status. $60.7 \%$ unvaccinated children belong to class IV and only $1.1 \%$ unvaccinated children were class I socioeconomic status.

\section{Discussion}

Immunization coverage gradually improving since last two decades, but age appropriate coverage is still less than $50 \%$. There is lot of factors that influence the acceptance of vaccination coverage in under five years of age. In our study though $55.3 \%$ children were male and $44.6 \%$ were female, but both were almost equally vaccinated $(58.9 \%$ male Vs $59.2 \%$ female). This indicates gradually increasing awareness regarding 
vaccine preventable diseases and decrease in gender discrimination in society. Corsi et al (2009) in their study found that, girls were found to have significantly lower immunization coverage $(\mathrm{p}<0.001)$ than boys for $\mathrm{BCG}$, DPT, and measles [7]. In India, gender inequalities persist in most states. Male dominant Indian culture mainly responsible for this gender inequalities. Compare to global population of unvaccinated children $(20 \%)$, only $11.8 \%$ study population were unvaccinated for BCG [8].

With increasing age, numbers of drop out babies were increased and by DPT-3, 30.7\% and by 2 nd DPT booster $83.81 \%$ children were lost. Ignorance, lack of knowledge regarding vaccination, place and time is biggest reason $(55.8 \%)$ for non-vaccination, followed by shortage of time.

Basel PL et al (2012) also conclude high dropout rate (78.6\%) for BCG and measles vaccines. Female children were more likely to dropout than male. About $70 \%$ of children drop out were from labor class, and/or illiterate families [10]. But nowadays, because of proper tracking system and timely reminder facilities, drop out cases are decreased dramatically. Coverage with the third dose of DTP vaccine (DTP3) by age 12 months is a key indicator of immunization program performance. Estimated global DTP3 coverage has remained at $83 \%-84 \%$ since 2009 , with estimated 2013 coverage at $84 \%$ [9].

Best part of gradually increasing vaccination coverage is that, parents of poor socioeconomic status, now understanding that, these vaccines are important to prevent diseases. The results from our study, confirmed that maternal education has great impact on acceptance of complete vaccination. In unvaccinated category, 55.1\% mothers and $42.7 \%$ fathers are illiterate, which is consistent with findings from other studies [11,12]. Increase maternal knowledge regarding vaccination again increase acceptance for vaccination coverage [13]. Availability of a vaccination card showed a strong relationship with correct and complete vaccination status. Availability of the vaccination card, encourage mothers to complete the vaccination and avoid dropout. Acceptance of full vaccination coverage is also depends on women's, education, occupation and antenatal care. Women who are in job are usually more aware of health of their kids and other family members.

\section{Conclusions}

Despite the increase in healthcare services and various health programs in India, full immunization coverage for children younger than five is currently still highly inadequate. Satisfactory coverage is possible with holistic approach only. Increasing the health care centers in rural and slums, women education, small family norms, proper antenatal care, media promotion and political willpower are different steps that can increase vaccination coverage. Steps for improvement should focus on reducing the dropout rate from BCG to measles, measles to DPT Booster-1 and DPT Booster-1 to DPT-Booster-2.

\section{Conclusion}

Survival is a big challenge for children younger than five years old, especially for those under one year. Immunization is the one of the most effective ways of protecting the health of children against some of the most lethal diseases. Despite the increase in healthcare services and various health programs in India, full immunization coverage for children younger than five is currently still highly inadequate.

\section{Funding: Nil \\ Conflict of interest: Nil \\ Permission from IRB: Yes}

\section{References}

1. Chowdhury AMR, Aziz KMA, Bhuiya A. The 'near miracle' revisited: social science perspectives of the immunization program in Bangladesh. Amsterdam: Het Spinhuis, 1999:138.

2. CDC, "Ten great public health achievement-United States, 1900-1999," Morbidity and Mortality Weekly Report, vol. 48, pp. 241-243, 1999.

3. World Health Organization. World Health Statistics 2011. Available at: http://www.who.int/entity/gho/publications/world_health statistics/EN_WHS2011_Full.pdf. Accessed on 27 November 2014.

4. Bonu S, Rani M, Baker TD. "The impact of the national polio immunization campaign on levels and equity in immunization coverage: Evidence from rural North India”. Social Science Medicine.2003; 57:1807-19.

5. National Family Health Survey-II (1998-'99), J\&K State (2002). International Institute for Population Sciences, Mumbai, p 129.

6. Sharma B, Mahajan H, Velhal GD. "Immunization Coverage: Role of Sociodemographic Variables," Advances in Preventive Medicine. vol. 2013, Article ID 607935, 5 pages, 2013. doi:10.1155/2013/607935.

7. Corsi DJ, Bassani DG, Kumar R, Awasthi S, Jotkar R, Kaur N, Jha P. Gender inequity and age-appropriate immunization coverage in India from 1992 to 2006. BMC Int Health and Human Rights. 2009; 9(Suppl I): S3.

8. Worldwide, 20 per cent of children go unvaccinated. The Independent: 2015 Mar 12. 
9. Harris JB, Gacic-Dobo M, Eggers R, Brown DW, Sodha SV. Global Routine Vaccination Coverage. Weekly 2014 Nov 21; 63(46);1055-1058.

10. Basel PL, Shrestha IB. Factors associated with dropout between Bacille Calmette Guerin (BCG) and measles vaccination in a village development committee of a district. J Nepal Health Res Counc. 2012 May;10(21):147-51.

11. Phukan RK, Barman MP, Mahanta J. Factors associated with immunization coverage of children in
Assam, India: over the first year of life. J Trop Pediatr (2009) 55 (4): 249-252.

12. Ibnouf AH,Van den Borne HW, Maarse JAM. Factors influencing immunization coverage among children under five years of age in Khartoum State, Sudan. South African Journal of Family Practice 2007;49(8). 14-14F.

13. Suarez L, Simpson DM, Smith DR. The impact of public assistance factors on the immunization levels of children younger than 2 years. Am J Pub Health 1997;87:845-8.

\section{How to cite this article?}

Maheshwari M, Gedam DS, Patel U, Masood A. Factors affecting the vaccination coverage of children under five years in central India. Pediatr Rev: Int J Pediatr Res 2014;1(1):34-39. doi: 10.17511/ijpr.2014.i01.08 